\title{
THE CONTRIBUTION OF REPRESENTATIVES OF THE ORDER OF ST. BASIL THE GREAT IN THE PRESERVATION OF NATIONAL-CULTURAL RELATIONS OF UKRAINIANS IN CANADA IN THE XX CENTURY
}

\section{Anatoliy Bodrug}

Post-graduate student

of the Department of History of Ukraine

Odessa I. I. Mechnikov National University

2, Dvoryanska Str., Odessa, 65082, Ukraine

metall.feniks@yandex.ua

The purpose of this scientific article is to highlight the issue of the role of representatives of the Ukrainian Greek Catholic Church in the national-cultural process, which takes place among the Ukrainian diaspora in Canada. It is the activity of the monastic Order of St. Basil the Great that is a vivid example of devotional service to the Ukrainian people, given its stay far beyond the ethnic territory. To achieve this goal, the required number of sources and historiographic literature was drawn that dealt with various aspects of the problem raised. The author applied the following general historical scientific research methods, as historical-genetic, historical-comparative and historical-typological. As part of this study, the spiritual and social activities of prominent Basilians of Canada were reviewed. The author explores the contribution of the Order of St. Basil the Great to the preservation of the national identity and spirituality of our people. Particular attention is devoted to the study of the role of the Order in the educational process of the Ukrainian diaspora of Canada. For the first time an attempt was made to summarize various aspects of the problem.

Key words: Ukrainian diaspora of Canada, Order of Saint Basil the Great, national-cultural relations, spiritual life of the diaspora, educational processes.

Анатолій Бодруг

Аспірант кафедри історії України, Одеський національний університет імені I. I. Мечникова Вум. Дворянська, 2, Одеса, 65082, Україна metall.feniks@yandex.ua

\section{ВНЕСОК ПРЕДСТАВНИКІВ ОРДЕНУ СВЯТОГО ВАСИИІЯ ВЕАИКОГО У ЗБЕРЕХЕННЯ НАЦІОНАМЬНО-КУАЬТУРНИХ ЗВ'ЯЗКІВ УКРАЇНЦІВ КАНАДИ У XX Ст.}

Мета даної наукової статті полягає у висвітленні питання ролі представників Української греко-католииької иеркви у національнокультурному проиесі, шо має місие в осередку украӥнської діаспори Канади. Саме діяльність чернечого Ордену святого Василія Великого $є$ яскравим прикладом відданого служіння украӥнсъкому народу, з огляду на його перебування далеко за межами етнічної території. Для досягнення зазначеної мети було залучено необхінуу кількість джерел та історіографічної літератури, які торкались різних аспектів порушеної проблеми. Автором було застосовано такі загальноісторичні наукові методи дослідження, як історико-генетичний, історико-порівняльний та історико- 
типологічний. В межах даного дослідження було розглянуто духовну та громадську діяльність видатних Василіян Канади. Автором досліджується внесок Ордену святого Василія Великого у збереження національної ідентичності та духовності нашого народу. Окрема увага присвячена вивченню ролі Ордену у освітньому проиесі українсъкої діаспори Канади. Вперше здійснена спроба узагальнення різних аспектів проблеми.

Ключові слова: українсъка діаспора Канади, Орден святого Василія Великого, наиіонально-культурні зв'язки, духовне життя діаспори, освітні проиеси.

«Нема, мабуть, давнішої колонії в Канаді, що в ній не працювали б Отці Василіянського Чина..." [12, с. 6] - відзначав церковний діяч, василіянин, єпископ Української греко-католицької церкви в Канаді та член НТШ Николай Саварин. Безперечно, не можна недооцінити той вагомий внесок, який внесли в справу об’єднання канадської громади українців представники грекокатолицького чернечого Ордену святого Василія Великого. Варто зазначити, що ще 3 часів існування Київської Русі християнство стало важливим консолідуючим фактором народу, а питання релігії завжди були тим наріжним каменем, який турбував український народ багато століть тому та $\epsilon$ актуальним і зараз. В часи нелегких випробувань, які випали на долю нашого народу, церква також змінювала своє буття, що супроводжувалось появою нових вчень та конфесій, зрештою, направлених на досягнення політичного компромісу та релігійного миру між різними народами у тому чи іншому етнічному регіоні нашої території. Яскравим прикладом цього може служити Берестейська унія 1596 р., яка за рішенням Синоду єпископів Київської митрополії та митрополита Михайла Рагози стала кроком у збереженні східної християнської традиції і власної церковної та етнокультурної самобутності від свавіляя поляків та московського зазіхання. Хоча греко-католики і визнали вцаду Папи Римського та догмати католицької церкви, але зберегли водночас православні обряди та надалі проводили службу церковнослов'янською мовою, що давало змогу, у тяжких для православного обряду умовах, зберігати деякі складові останнього. Дия збільшення числа прихицьників унії та розвитку греко-католицької церкви було створено нові ордени або чини св. Василія Великого та Феодора Студита, які діяли за уставами відповідних святих. Василіанський чин тісно пов'язаний з Берестейською унією. Можна сказати, що вона його зродила, а він - за словами митрополита Рутського - став "єдиним засобом поширення унії на Русі" [11, с. 79]. На початку XVII ст. на капітулі в с. Новгородовичі представники п'яти унійних монастирів за ініціативою митрополита Й. В. Рутського та архієпископа Й. Кунцевича об’єдналися в єдиній Конгрегації Пресвятої Трійці - під керівництвом виборного протоархімандрита, що зробило їх незалежними від єпископів. Незабаром було проведено реформу монашого життя та створено Чин святого Василія Великого (ЧСВВ) або Василіянський Чин св. Йосафата. Впродовж XVIIXVIII ст. представники ЧСВВ допомагали нужденним, опікувались школами i гімназіями, засновували друкарні і бібліотеки, здійснювали будівництво церков, створювали релігійні твори та сприяли іконопису. На українських землях, які за результатом трьох поділів Польщі потрапили під юрисдикцію Російської імперії, поступово здійснювались утиски української духовної та національно-культурної еліти. У XIX ст. місійна й культурницька діяльність василіан-унійців звузилася, 1839 р. в Російській імперії указом імператора Миколи I вона була остаточно заборонена, а в Галичині й Закарпатській 
Україні, що перебували в складі Австрійської імперії (3 1867 - АвстроУгорщина), значно обмежена [9, с. 442]. У другій половині ХІХ ст. ЧСВВ відчував потребу у оновленні. 3 цією метою у 1882 р. папа $\Lambda$ ев XIII доручив єзуїтам провести реформу ордену, яку було започатковано в монастирі в Добромилі. Після проведення реформи василіяни продовжили власну освітню та видавничу діяльність. Важливою віхою у релігійному житті ордену стало здійснення місіонерської діяльності у еміграції, зокрема у Канаді.

Актуальність даного дослідження пов'язана з сучасним станом української релігійної політики, окремою складовою якої $є$ діяльність греко-католицького чернечого ордену - Чину святого Василія Великого та його внеску у збереження національно-духовних цінностей української діаспори Канади.

Окремі аспекти даної проблеми були розкриті в працях таких дослідників, як: Залуцька Г. І. [3], Марунчак М. Г. [7], Підручний П. В. [11] та Шкраб'юк П. В. [15]; [16]; [17]. Проте, на наш погляд, діяльність Ордену святого Васимія Великого у еміграції варта більшої уваги, а його роль у духовному та національно-культурному процесі української діаспори Канади потребує ретельнішого дослідження. Досить важливим є розкриття основних аспектів духовного світу українського грома-дянина в еміграції у світлі державної політики Канади та світових історичних подій.

У кінці XIX ст. соціально-економічне становище складалось не на користь українського народу, а національно-культурні утиски з боку австрійського та російського урядів наводими на думку про пошук кращого місця дия життя та вільного ведення господарства. В цей час українство починає шукати кращу долю за океаном, насамперед у Канаді. Політичні заклики та пропаганда описувала країну Північної Америки, як райську землю, проте насправді українці, які домали нелегку дорогу мандрівників-емігрантів, потрапляли у довгі, кам'яні пустелі, необроблені хащі Онтаріо, гірську місцевість зі споконвічними пралісами та болотами у підніжжя провінції Альберта. Дия того щоб майже за півстоліття перетворити цілинні землі Канади у гарно оброблені пшеничні поля українцям потрібно було надзвичайно тяжко працювати за умови північного клімату. Наші співвітчизники потребували у часи фрізичного та морального спустошення великої духовної підтримки. У вирі мультикультурного контексту досить важко було зберігати свою релігійну приналежність та національну ідентичність. Тому, зважаючи на ці обставини, українська греко-католицька церква, а саме представники Чину святого Василія Великого (ЧСВВ) почала здійснювати місіонерські подорожі до Канади. 1 мистопада 1902 р. до м. Едмонтона (провінція Ацьберта) прибули перші священики-василіяни: П. П. Філяс, С. Дидик, А. Строцький і брат $€$. Янишевський, які стали першими Василіанами на території Канади. Діяльність перших місіонерів призвела до створення цілої низки національнодуховних освітніх центрів. "Зараз по приїзді поділились Отці кольоніями: о. Філяс забрав у духовну обслугу Біверлейк і околицю; о. Дидик - Реббіт Гілм і околицю; о. Строцький - Стар... Прочі Отці занялись місійною працею у Вінніпегу... Зачалась організація перших парохій, а відтак і будова церков" [12, с. 19]. У 1932 р. представники ЧСВВ починають діяти у центрі провінції Квебек - м. Монреалі. Згодом васиміани розпочали плідну працю в Едмонтоні, який 1948 р. став осідком екзархату Західної Канади [3, с. 15]. В 1949 р. - у Торонто, а в 1958 р. - Оттаві. Отже, до початку 60-х рр. ХХ ст. своєю духовною, культурницькою та просвітницькою діяльністю Василіянський орден охопив практично всю Канаду. 
Здійснюючи місіонерську діяльність на території Канади, василіяни розуміли, що в місцях поселення української спільноти необхідно розпочати будівництво церков, які стануть не тільки духовними, а і освітніми осередками. У межах даної статті доречно розглянути найголовніші храми, збудовані за

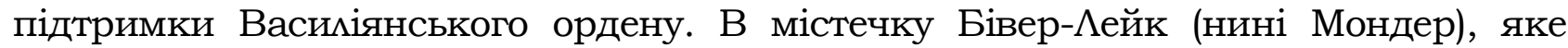
стало першим важливим форпостом ЧСВВ, у 1910 р. на кошти української громади та за підтримки васіліан було побудовано церкву Св. Петра і Павца, яка проектувалась з огляду на споконвічні українські архітектурні традиції. Відомо, що землю під будівництво храму пожертвував українець М. Шевчук. В день урочистого освячення церкви виступив прем'єр-міністр Канади Вільфред $\Lambda$ ор'є, що вказує на велику підтримку української діаспори з боку вищого керівництва держави вже у роки першої хвилі еміграції. Важливим центром отців-василіян був Вінніпег, провінція Манітоба. У 1947 р. у Вінніпезі розпочалось будівництво Собору святих Володимира і Ольги за проектом архітектора Дж. Н. Семменсона. Через матеріальні труднощі, спричинені Другою світовою війною, будівництво було завершено тільки в 1951 р. Після освячення храм отримав статус кафедрального собору архієпархії Вінніпегу. Церква святого Архангела Михаїла перша греко-католицька українська церква в Монреалі, яка була збудована у 1917 р. У 1932 р. почався Василіанський період в історії церкви, коли парохом став о. Йосафат Тимочко. У 1954 р. стару церкву було зруйновано та на старому фундаменті зведена нова будівля, яка існує і нині. Михайлівська церква збудована у візантійському стилі та має відповідні вежі та інтер'єр. Візантійські ікони та фрески з зображенням святих, а також українських князів та королів, прикрашають стіни та стелю. У 1947 р. представниками Василіянського ордену у Едмонтоні було відкрито собор святого Йосафата, будівництво якого тривало 8 років. В наступному році церква стає центром Апостольського екзархату УГКЦ. Пізніше храм отримує статус кафедрального собору Едмонтонської єпархії. В оздобленні храму присутні елементи українського бароко, які поєднані 3 рисами західноєвропейського стилю. В 1962 р. в м. Торонто представники ЧСВВ заклали початок будівництва собору Покрови Святої Богородиці за проектом архітекторів Є. Ірея та Р. Думина. Освячення церкви відбулось в 1964 р. За своїм стилем собор відноситься до козацького бароко та зпроектований 3 чотирма каплицями, на балконі, по обох сторонах хорів та святилища. Інтер'єр храму прикрашає балкон від іконостасу до хорів. Розпис іконостасу виконав український художник С. Я. Гординський. Потреба у будівництві церкви в Оттаві виникла ще в 1914 р., коли з'явилась греко-католицька парафія в провінції Онтаріо. Проте знадобимось майже 73 роки поневірянь, коли в 1987 р. в столиці було збудовано церкву святого Івана Хрестителя у стилі українського бароко з елементами норманської готики. Церква, у юрисдикції Отців Василіян, відразу отримала статус собору та національної пам'ятки. Освячення собору присвятили пам'яті тисячоліття християнства в Україні (988-1988 рр.). Внутрішнє оздоблення церкви (іконографія та вітражі) здійснювали Аюбомир Медвідь та Степан Юзефів зі Аьвова і проходицо воно з 1999 по 2000 рр.

Отець-василіянин Никон Свірський у своїх спогадах відзначав: "Другою пекучою справою були школи. Бракувало вчителів, що навчали б дітей також і рідної мови" [13, с. 21]. I дійсно, вагому роль у розвитку освіти у середовищі української діаспори відіграли члени василіянського ордену. Вперше василіяни почали відкривати недільні школи при церквах та монастирях, де навчали селянських дітей рідної мови та духовної моралі. Пізніше було засновано цілу низку парафіяльних шкіл та розпочато підтримку бурсів $\mathrm{i}$ семінарій. Початкові школи, які створювалися з ініціативи ЧСВВ, були 3-х 
типів: цікоденні, вечірні та мітні. У 1905 р. 3 ініціативи о. Матея Гури у Вінніпезі було відкрито школу св. Миколая, де крім освітньої проводицась виховна та культурницька робота. У 1913 р. за допомогою о. Н. Крижа-

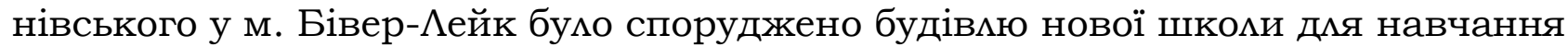
дітей українських селян. Окрім обов'язкових дисциплін, визначених державним департаментом освіти для публічних шкіл, тут вивчалися українська мова, історія України, релігія, мистецтво (різьблення, вишивка, писанкарство). У додатковий час працювали музичний, хоровий, драматичний, танцювальний гуртки [3, с. 15-16]. В 1945 р. було створено школу-інтернат у Едмонтоні, яка складалась 3 Інституту св. Василя дия хлопців та Інституту св. Йосафата для дівчат, метою яких стало духовне та національне виховання молоді, що мало б запобігти асиміляційним процесам. Влітку 1946 р. отці ЧСВВ Слобода, Курило та Мефодій Козяк, організували "Курси мідерства", спочатку в Саскатуні, а з 1950 р. у Едмонтоні. У 1962 р. було засновано Комегію св. Василія Вецикого у Вестоні (північний захід м. Торонто), яка вважається першою українською середньою школою для хлопців у Східній Канаді. Викладали в колегії винятково отці-василіяни та готували молодь у вступ до канадських вишів. В 1980 р. василіянами було засновано вищий навчальний заклад в Оттаві - Семінарію Святого Духа. Ректором семінарії було призначено відомого релігійного діяча о. Йосипа Андрійшина. 3 вересня 1981 p. семінарія почала приймати студентів. Навчальна програма відповідала греко-католицькій системі, яка була розроблена отцями-василіянами та містила поглиблене вивчення філософії та богослов'я. Фінансову підтримку здійснювали представники ЧСВВ та небайдужі українці.

Опікувались отці-василіяни і видавничою справою у Канаді. Вже від самих початків українського поселення в Канаді потреба рідної католицької преси була надзвичайно пекучою справою [6, с. 1]. Українська діаспора відчувала потребу у виданні релігійної мітератури та греко-католицької періодики, бо саме зі шпальт українці отримували інформацію про життя нашого народу, як на території Радянської України, так і у всьому світі. Українські видання містили твори минулих та сучасних мітераторів, а також сповіщали про потреби та досягнення української громади Канади. Зрештою, українська мітература допомагала зберігати споконвічні традиції, мову, історичну пам'ять нашого народу. В 1906 р. на нараді у Вінніпегу чцени ЧСВВ вирішили заснувати власну друкарню та започаткувати видання часопису. Проте тоді цей намір було важко здійснити через брак коштів. У 1909 р. на першому Всеканадійському Католицькому Соборі у Квебеку о. Созонт Дидик, тодішній настоятель Василіянської Місії в Канаді, вніс на порядок денний питання про початок друку першого греко-католицького україномовного часопису в Канаді. За сприянням місіонера та за підтримки отців-василіян і простих селян у 1911 р. було засновано український тижневик "Канадійський Русин" (з 1918 р. "Канадійський Українець»). Аадика В. В. - єпископ Української греко-католицької церкви, другий єпископ УГКЦ у Канаді заснував в Едмонтоні у 1929 р. новий католицький тижневик «Західні Вісті» (з 1931 р. "Українські Вісті»). У 1937 р. отці-василіани відкрили друкарню ЧСВВ в Мондері. Протоігумен о. Навкратій Крижановський на власні кошти придбав фонди на будову першої василіянської друкарні в Канаді та особисто наглядав за їі роботою. 3 травня 1938 р. почав виходити друком часопис "Світло" (з 1949 р. друкується у Торонто) та 4-х томне видання "Життя Святих" о. Андрія Труха. У Мондері Василіяни видавали 
окрім релігійної мітератури багато книжок 3 ділянки української історії, культури і різних галузей науки. Статті "Світла" на різні теми, як: віра, Церква, історія, мітература, цікаві оповідання, спомини, приклади і т. п. подавали читачам поучення потрібні до погмиблення й закріплення їх у

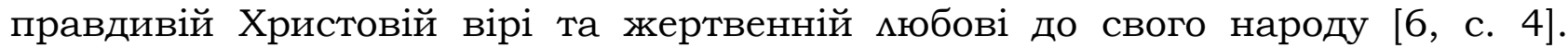
Видатні отці-василіяни, які займались виданням часопису "Світло": А. Трух, Ip. Назарко, Б. Дрібненький, Н. Свірський, М. Соловій та О. Купранець. У 1930-х рр. завдяки старанням о. І. Дамаскина Поповича було відкрито василіянську "Бібліотеку Добрих Книжок", фонди якої поповнювались грекокатолицькими книжками з усього світу. Найбільше мітератури було привезено з Західної України, Німеччини, Чехослозаччини, Бельгії, США та Бразилії. Налічувала книгозбірня велику кількість мітургійних та релігійних видань: духовні науки, молитовники, белетристичні, наукові, історичні видання та ін. Звідси почалося й закладання бібліотек по парафіях і товариствах.

Якщо розглядати діяльність отців-василіян то їх робота відзначалась не мише духовними та просвітницькими аспектами. Важливою сторінкою історії Василіянського ордену в Канаді є збереження культурної спадщини народу, що вилилось у створення музеїв. В 1953 р. на місці колишньої друкарні, перенесеної в 1949 р. до Торонто, в Мондері було відкрито Музей книгодрукування. Фонди музею містять велику кількість експонатів, серед яких слід видікити старовинні рукописи, релігійні стародруки, документи, мисти а також серію картин зі зображенням українських церков та їх макети. До того ж фонди музею можуть похвалитись Острозькою Біблією 1580 р. При монастирі Василіян у Мондері в 1957 р. почав діяти Музей отців Василіян, який представляє історію українського селища та Василіянського ордену. В музеї знаходяться релігійні артефакти, а також унікальні колекції українських писанок, вишиванок, селянських знарядь праці і предметів народного мистецтва. Музей отців Василіан має великий архів, який допомагає українським вченим також у дослідженні перших хвиль української еміграції до Північної Америки. Відомо, що поповнення колекцій музею здійснювало багато відомих отці-василіян, серед яких можна виділити одного з засновників музею та палкого прихимьника України, француза за походженням, о. Йосафата Жана, який зробив також вагомий внесок у розвиток української діаспори Канади. Український історик та мітературознавець Петро Шкраб’юк характеризує священика, як римокатолика який перейшов на східний обряд, вступив до монашого Чину отців васиціян, а в 1918-1921 рр. брав участь в українському державотворенні [17, c. 152]. 3 нагоди святкування Незалежності України та відзначення 100-річчя українського селища в Канаді у 1991 р, отці-василіяни урочисто відкрили новий корпус музею, де було представлено виставку колекцій українських релігійних та народних експонатів, які розповідають нам про історію Української греко-католицької церкви в Канаді з 1902 по 1991 рр.

Таким чином, внесок представників Ордену святого Васимія Великого у збереження національно-кумьтурних зв'язків української діаспори Канади $\epsilon$ дійсно вагомим та різнобічним. За свою багатовікову історію орден завжди дотримувався своєї головної мети - за будь-яких умов допомагати та об'єднувати ближніх незалежно від місця їх географічного розселення. Саме тому отці-василіяни у межах Речі Посполитої, Австро-Угорської та Російської імперій упродовж XVII-XVIII ст. допомагали нужденним, опікувались школами, засновували друкарні і бібліотеки, зводили церкви та створювали релігійні твори, а на початку XX ст. продовжили своє почесне служіння 
народу України на території Канади. Початок своєї місії у Канаді василіяни пов'язали з м. Бівер-Һейк. Саме там у 1902 р. з'явився першим монастир, там у 1910 р. було збудовано церкву Св. Петра і Павла, а у 1913 відкрито одну з перших шкіл для дітей українських семян. Змінивши свою назву на Мондер, це місце стало важливим видавничим та культурним центром. Так, у 1937 р. в Мондері було відкрито друкарню ЧСВВ де виходили друком видання релігійного та наукового спрямування. В 1953 р. розпочає свою роботу Музей книгодрукування, а в 1957 р. - Музей отців Василіян, які всіх знайомлять 3 духовними та культурними досягненнями нашого народу. Важливу роботу на всіх вище зазначених напрямках василіяни здійснювали у Вінніпезі, Монреалі, Едмонтоні, Торонто та Оттаві. Отже, представникам Василіянського ордену випала доля стати піонерами у багатьох галузях не тільки релігійного, а і світського життя українства Канади, проте їх робота має продовження i в нашу непросту історичну добу - національнокультурного зростання незалежної держави - України.

\section{Джерема та пітература:}

1. Ваврик М. М. По василіянських монастирях / М. М. Ваврик. - Торонто : Видавництво Василіян, 1958. - 286 с.

2. Васиміяни // Філософський енциклопедичний словник / редкол. : В. І. Шинкарук (голова) та ін. - К. : Абрис, 2002. - С. 72-73.

3. Залуцька Г. І. Освітні аспекти діяльності чину святого Василія Великого під час перших трьох хвиль еміграції українців до Канади (початок XX ст. - 60-ті роки XX ст.) / Г. І. Залуцька // Педагогічні науки / за ред. В. А. Федяєвої. Херсон : Херсонський державний університет, 2017. - Вип. LXXVII. Том 1. C. $14-17$.

4. Йосафат I. Ж. Національно-громадянська праця василіянських отцівпіонерів / I. Ж. Йосафат. - Ванкувер : Pillar of Fire, 2001. - 44 с.

5. Казимира Б. Д. Перший васиміянин у Канаді / Б. Д. Казимира. - Торонто : Добра книжка, 1961. - Вип. 166. - 40 с.

6. Марко М. Р. Васиціяни - піонери друкованого слова / М. Р. Марко, I. П. Дамаскин, П. П. Поманський. - Ванкувер : Pillar of Fire, 2001. - 17 с.

7. Марунчак М. Г. Історія українців Канади / М. Г. Марунчак. - Вінніпег : УВАН в Канаді, 1991. - Т. 1. - 464 с.

8. Мельничук Б. І., Уніят В. Б. Жан Йосафрат-Іван / Б. І. Мемьничук, В. Б. Уніят // Тернопільський енциклопедичний словник : у 4 т. / редкол. : Г. I. Яворський та ін. - Тернопімь: Видавничо-поміграфічний комбінат "Збруч", 2004. - Т. 1 : А - Й. - С. 569.

9. Паславський I. В. Васиміани (базиміяни) / I. В. Паславський // Енциклопедія історії України : у 10 т. / редком. : В. А. Смолій (голова) та ін. ; Інститут історії України НАН України. - К. : Наукова думка, 2003. - Т. 1 : А B. - C. 442-443.

10. Патрило I. І. Джерела і бібліографія історії Української Церкви / І. I. Патрило. - Рим : Васиміяни, 1975. - 376 с.

11. Підручний П. В. Початки Василіанського чину і Берестейська унія / П. В. Підручний // Берестейська унія та внутрішнє життя Церкви у XVII

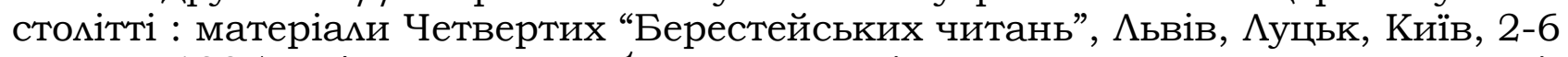
жовтня 1995 р. / за ред. Б. А. Гудзяка. - Аьвів : Видавництво Інституту Історії Церкви Аьвівської Богословської Академії, 1997. - С. 79-124.

12. Саварин Н. В. Роль Отців Василіян у Канаді / Н. Н. Саварин. - Мондер : Видавництво Васиміян, 1938. - 60 с. 
13. Свірський Н. Н. Туди минуть наші серця (Історія мондерського манастиря) / Н. Н. Свірський. - Мондер-Торонто : Видавництво Василіян, 1963. -88 c.

14. Світлій памяті василіян-піонерів / за ред. В. О. Гайдука. - Мондер : Видавництво ОО. Васиміян, 1963. - 120 с.

15. Шкраб'юк П. В. Монаший Чин Отців Василіян у національному житті України / П. В. Шкраб'юк. - Аьвів : Видавництво Отців Василіян - Місіонер, 2005. - 439 c.

16. Шкраб’юк П. В. Монаший Чин Отців Василіян у суспільно-культурному житті України : автореф. дис. ... док. іст. наук / П. В. Шкраб’юк; Інститут українознавства ім. І. Крип'якевича НАН України. - Аьвів, 2007. - 34 с.

17. Шкраб'юк П. В. Спогади француза з Квебеку отця Жана, ЧСВВ, як засіб концептуалізації конфесійної та національної ідентичности / П. В. Шкраб'юк // Вісник Аьвівського університету. Серія журналістики / за ред. М. Г. Житарюка. - Һьвів : Видавництво АНУ ім. І. Я. Франка, 2006. - Вип. 28. - С. 152-156.

18. Klymasz R. B. The Ukrainians in Canada, 1891-1991. National Museums of Canada / R. B. Klymasz. - Ottawa : Published by the Canadian Museum Civilization and the National Museum Science and Technology, 1989. - 128 p.

19. Yuzyk P. M. The Ukrainian Greek Orthodox Church of Canada 1918-1951 / P. M. Yuzyk. - Ottawa : University of Ottawa Press, 1981. - 210 p.

\section{Referenses:}

1. Vavryk, M. M. (1958). Po vasyliyans'kykh monastyryakh. Toronto: Vydavnytstvo Vasyliyan. [in Canadian].

2. Vasyliyany (2002). In V.I. Shynkaruk (Ed.), Filosofs'kyy entsyklopedychnyy slovnyk (pp. 72-73). Kyiv: Abrys. [in Ukrainian].

3. Zaluts'ka, H. I. (2017). Osvitni aspekty diyal'nosti chynu svyatoho Vasyliya Velykoho pid chas pershykh tr'okh khvyl' emihratsiyi ukrayintsiv do Kanady (pochatok XX st. - 60-ti roky XX st.) [The Educational Aspects Of Osbm Activity At The Time of The First Three Waves Of Ukrainian Emigration To Canada (the Beginning Of The XX-th Century-60-th Years Of The XX-th Century)] V. L. Fedyayeva, (Ed.). Pedahohichni nauky - The pedagogical sciences, (LXXVII, 1), 14-17. [in Ukrainian].

4. Yosafat, I. Zh. (2001). Natsional'no-hromadyans'ka pratsya vasyliyans'kykh ottsiv-pioneriv. Vankuver: Pillar of Fire. [in Canadian].

5. Kazymyra, B. D. (1961). Pershyy vasyliyanyn u Kanadi. (Vol. 166). Toronto: Dobra knyzhka. [in Canadian].

6. Marko, M. R., Damaskyn, I. P., \&Polans'kyy, P. P. (2001). Vasyliyany pionery drukovanoho slova. Vankuver: Pillar of Fire. [in Canadian].

7. Marunchak, M. H. (1991). Istoriya ukrayintsiv Kanady. (Vol. 1). Vinnipeh: UVAN v Kanadi. [in Canadian].

8. Mel'nychuk, B. I., \& Uniyat, V. B. (2004). Zhan Yosafat-Ivan. In H.I. Yavors'kyy (Ed.), Ternopil's'kyy entsyklopedychnyy slounyk: u 4 tomakh (Vol. 1, p. 569). Ternopil": Vydavnycho-polihrafichnyy kombinat "Zbruch". [in Ukrainian].

9. Paslavs'kyy, I. V. (2003). Vasyliany (bazyliyany). In V.A. Smolii (Ed.), Entsyklopediya istoriyi Ukrayiny: u 10 tomakh (Vol. 1, pp. 442-443). Kyiv: Naukova dumka. [in Ukrainian].

10. Patrylo, I. I. (1975). Dzherela i bibliohrafiya istoriyi Ukrayins'koyi Tserkvy. Rome: Vasyliyany. [in Italian]

11. Pidruchnyy, P. V. (1997). Pochatky Vasylians'koho chynu i Beresteys'ka uniya. Abstracts of Papers '95: Beresteys' ka uniya ta vnutrishnye zhyttya Tserkvy u XVII stolitti: "Beresteys'ky chytannya'". (pp. 79-124). L'viv: Vydavnytstvo Instytutu Istoriyi Tserkvy L'vivs'koyi Bohoslovs'koyi Akademiyi. [in Ukrainian]. 
12. Savaryn, N. V. (1938). Rol' Ottsiv Vasyliyan u Kanadi. Monder: Vydavnytstvo Vasyliyan. [in Canadian].

13. Svirs'kyy, N. N. (1963). Tudy lynut' nashi sertsya (Istoriya monders'koho manastyrya). Monder-Toronto: Vydavnytstvo Vasyliyan. [in Canadian].

14. Hayduk, V. O. (Ed.). (1963). Svitliy pamyati vasyliyan-pioneriv. Monder : Vydavnytstvo OO. Vasyliyan. [in Canadian].

15. Shkrab'yuk, P. V. (2005). Monashyy Chyn Ottsiv Vasyliyan u natsional'nomu zhytti Ukrayiny. L'viv: Vydavnytstvo Ottsiv Vasyliyan - Misioner. [inUkrainian].

16. Shkrab'yuk, P. V. (2007). Monashyy Chyn Ottsiv Vasyliyan u suspil'nokul'turnomu zhytti Ukrayiny [Monastic Order of Basilian Fathers in the SocialCultural Life of Ukraine] (Extended abstract of Doctor's thesis). L'viv. [in Ukrainian].

17. Shkrab'yuk, P. V. (2006). Spohady frantsuza $z$ Kvebeku ottsya Zhana, CHSVV, yak zasib kontseptualizatsiyi konfesiynoyi ta natsional'noyi identychnosty [Flashbacks Of Father Jean, Frenchman From The Quebec, RSBG, As Method Of Conceptualization Of Confession And National Identity] (M. H. Zhytaryuk, Ed.). Visnyk L'vivs'koho universytetu. Seriya zhurnalistyky Visnyk of Lviv University. A series of journalism, (28), 152-156. [in Ukrainian].

18. Klymasz, R. B. (1989). The Ukrainians in Canada, 1891-1991. National Museums of Canada. Ottawa: Published by the Canadian Museum Civilization and the National Museum Science and Technology. [in Canadian].

19. Yuzyk, P. M. (1981). The Ukrainian Greek Orthodox Church of Canada 19181951. Ottawa: University of Ottawa Press. [in Canadian].

\section{Вклад представителей Ордена святого Василия Великого в сохранение национально-культурнъх связей украинцев Канады в XX в.}

Цель данной научной статьи заключается в освешении вопроса роли представителей Украинской греко-католической иеркви в наииональнокультурном проиессе, что имеет место в среде украинской диаспорь Канадъ. Именно деятельность монашеского Ордена святого Василия Великого является ярким примером преданного служения украинскому народу, учитывая его пребывание далеко за пределами этнической территории. Для достижения указанной иели было привлечено необходимое количество источников и историографической литературы, которые касались различных аспектов затронутой проблемы. Автором бъли применены следуюшие обшеисторические научные методы исследования, как историко-генетический, историко-сравнительный и историкотипологический. В рамках данного исследования было рассмотрено духовную и обиественную деятельность выдаюшихся Василиян Канады. Автором исследуется вклад Ордена святого Василия Великого в сохранение наииональной идентичности и духовности нашего народа. Особое внимание посвящено изучению роли Ордена в образовательном проиессе украинской диаспоры Канады. Впервые предпринята попытка обобшения различных аспектов проблемь.

Ключевые слова: украинская диаспора Канады, Орден святого Василия Великого, наиионально-культурные связи, духовная жизнь диаспоры, образовательные процессы.

Отримано 21.11.2018 p. 